\title{
ANALISIS PEMANFAATAN LAHAN MELALUI SISTEM INFORMASI GEOGRAFIS DI KECAMATAN BATALAIWORU
}

\author{
Hasrah Febryana ${ }^{1}$ \\ ${ }^{1}$ Program Studi Pendidikan Geografi, Universitas Halu Oleo, Kendari.
}

\begin{abstract}
Abstrak: Berbagai fenomena perubahan penggunaan lahan telah terjadi dari waktu kewaktu. Perubahan penggunaan lahan yang terjadi sejalan dengan semakin meningkatnya pertambahan jumlah penduduk yang secara langsung berdampak pada kebutuhan terhadap lahan yang semakin meningkat. Kecamatan Batalaiworu adalah salah satu bagian Kecamatan dari Kota Raha Kabupaten Muna. Kecamatan Batalaiworu mulai terlihat mengalami perubahan perubahan penggunaan lahan. Penelitian ini bertujuan untuk mendeskripsikan perubahan penggunaan lahan tahun 2017. Penelitian menggunakan analisis peta digital. Analisis peta digital dengan Sistem Informasi Geografis dilakukan dengan cara mendigitasi peta penggunaan lahan hasil interpreasi citra tahun 2007 dan 2017 untuk memperoleh perubahan luasan penggunaan lahan. Diperoleh perubahan penggunaan di Kecamatan Batalaiworu dari tahun 2007 hingga 2017 terjadi bervariasi, ada yang mengalami peningkatan dan ada yang mengalami pengurangan luas penggunaan lahan. Untuk luas lahan yang bertambah yaitu Pemukiman 87 menjadi 155 ha, Kebun Campuran 57 menjadi 144 ha, Lahan Terbuka 18 menjadi 22 ha, Tambak 55 menjadi 58 ha, Pasar 12 menjadi 20 ha, dan Lahan Kosong 86 menjadi 97 ha. Luas lahan yang berkurang yaitu Hutan Sejenis 469 menjadi 277 ha dan Bakau 150 menjadi 139 ha. Berdasarkan perubahan penggunaan lahan menunjukan hanya dilokasi berpendudukan dan jarak aksebilitas yang mempengaruhi perubahan penggunaan lahan di Kecamatan Batalaiworu secara signifikan. Hal ini terjadi karena hampir sama penduduk bertujuan untuk membangun yang lebih murah.
\end{abstract}

Kata Kunci: Sisten Informasi Geografis,Proses, Perubahan Penggunaan Lahan

\section{ANALYSIS OF LAND USING SYSTEM THROUGH GEOGRAPHIC INFORMATION SYSTEM IN BATALAIWORU DISTRICT}




\title{
Hasrah Febryana ${ }^{1}$
}

\begin{abstract}
Various phenomena of land use change have taken place from time to time. Changes in land use that occur in line with the increasing number of people who directly affect the need for increasing land. Batalaiworu Subdistrict is one part of the District of Raha City of Muna Regency. Batalaiworu subdistrict is starting to experience changes in land use change. This study aims to describe land use change in 2017. Research using digital map analysis. The analysis of digital maps with Geographic Information System is done by digitizing land use map of image interpreation in 2007 and 2017 to obtain land area change. Obtained changes in the use of Batalaiworu District from 2007 to 2017 varied, some experienced an increase and there is a reduction in land use. For the increased land area of settlements 87 to 155 ha, mixed garden 57 to 144 ha, open land 18 to 22 ha, pond 55 to 58 ha, market 12 to 20 ha, and 86 empty land to 97 ha. The reduced land area of the 469 kind of forest to 277 ha and mangrove 150 to 139 ha. Based on the change of land use shows only the location of population and distance of accessibility which influence the change of land use in Batalaiworu Sub-district significantly. This happens become because almost the same population aims to build a cheaper one.
\end{abstract}

\section{Keyword : System Information of Geography, Process, The Change of Land Area.}

\section{PENDAHULUAN}

Berbagai fenomena perubahan pengguanan lahan telah terjadi dari waktu ke waktu. Perubahan pengguanan lahan yang terjadi sejalan dengan semakin meningkatnya pertambahan jumlah penduduk yang secara langsung berdampak pada kebutuhan terhadap lahan yang semakin meningkat. Perubahan penggunaan lahan di Kecamatan Batalaiworu yang terjadi diduga dipengaruhi oleh proporsi jumlah penduduk yang bekerja di sector non pertanian, jumlah penduduk, jarak aksebilitas dan jumlah penduduk pendatang.

Penggunaan lahan sebagai tempat manusia untuk hidup dan bertahan itu seharusnya memperhatikan kemampuan fisik lahan agar tidak membahayakan kehidupan manusia seperti banjir, longsor, maupun erosi. Dari itu maka perlunya mengetahui perubahan penggunaan lahan yang secara cepat dan tepat dapat membantu manusia untuk menentukan pola penggunaan lahan yang tepatdalam menjaga keselamatan hidup mereka.

Masalah perkembangan kota pada saat ini telah menjadi masalah yang cukup pelik untuk diatasi dan sering memunculkan konsekuensi negative pada beberapa aspek, utamanya aspek lingkungan. Perkembangan kota membutuhkan lahan sebagai tempat hidup penduduk dengan aktivitasnya. Lahan merupakan suatu daerah dipermukaan bumi dengan sifat-sifat tertentu yang meliputi biosfer, atmosfer, tanah, lapisan geologi, hidrologi, populasi tanaman, binatang dan hasil kegiatan manusia masa lalu dan masa sekarang sampai pada tingkat tertentu.

Menurut Bintarto (1977), lahan dapat diartikan sebagai land settlement yaitu suatu tempat atau daerah dimana penduduk berkumpul dan hidup bersama, dimana mereka dapat menggunakan lingkungan setempat untuk mempertahankan, melangsungkan dan mengembangkan 
hidupnya. Dengan demikian sangatlah jelas bahwa setiap makluk hidup pasti membutuhkan lahan untuk tumbuh dan berkembang, berbagai aktivitas manusia di dalam ruang bumi ini tidak lepas dari fungsi lahan yang berbeda-beda dalam penggunaan lahan. Penggunaan lahan adalah segala campur tangan manusia, baik secara menetap ataupun berpindah-pindah terhadap suatu kelompok (SuRitohardoyo, 2002). Pertambahan jumlah penduduk kota berarti juga peningkatan kebutuhan lahan. Karena lahan tidak dapat bertambah, maka yang terjadi adalah perubahan penggunaan lahan yang cenderung menurunkan proporsi lahanlahan yang sebelumnya merupakan penggunaan lahan pertanian menjadi lahan non pertanian.Seseorang melakukan perubahan penggunaan lahan dengan maksud untuk memaksimalkan sumber daya lahan tersebut sehingga diharapkan akan memperoleh keuntungan yang maksimal pula.

Salah satu perangkat aplikasiSistem Informasi Geografismampu menganalisa dan menampilkan data-data yang berhubungan posisi-posisi di permukaan bumi.Terkait dengan penelitian ini, SIG menganalisa dan memetakan luasan area perubahan penggunaan lahanSIG dapat didefinisikan sebagai kombinasi perangkat keras dan perangkat lunak komputer yang memungkinkan untuk mengelola (manage), menganalisa, memetakan informasi spasial berikut data atributnya (data deskriptif) dengan akurasi kartografi (Basic, 2000 dalam Eddy Prahasta, 2002). yang dilakukan pemerintah Kabupaten Muna Kecamatan Batalaiworu.
Perubahan lahan di Kecamatan Batalaiworu merupakan salah satu fenomena perubahan suatu wilayah akibat campur tangan manusia. Dengan demikian penentuan perubahan luasan penggunaan lahan perlu untuk diketahui. Maka dilakukan analisis pemanfaatan lahan di Kecamatan Batalaiworu. Berdasarkan permasalahan di atas, yang menjadi tujuan dari penelitian ini adalah sebagai berikut: (1) mencatat dan melihat perubahan luasan lahan yang terjadi di Kecamatan Batalaiworu 2007 dan 2017; dan (2) mendeskripsikan peta sebaran perubahan penggunaan lahan pada tahun 2007 dan 2017 di Kecamatan Batalaiworu.

\section{METODE PENELITIAN}

\section{Daerah danWaktu Penelitian}

Pada penelitian ini lokasi yang digunakan adalah Kecamatan Batalaiworu. Secara administrasi terletak di Provinsi Sulawesi Tenggara di Kabupaten Muna.

\section{Survei Lokasi Penelitian}

Pada penelitian ini data yang digunakan adalah metode pengumpulan data primer dan sekunder. Pengumpulan data dengan survey primer melalui wawancara dan observasi yaitu untuk mengatahui kondisi lahan yang terjadi di Kecamatan Bata Laiworu. Data sekunder digunakan sebagai pelengkap datadata primer yang telah diperoleh. Metode pengumpulan data sekunder dalam penelitian ini adalah studi pustaka dan survei instansi. Kebutuhan data tersebut tersedia dalam dokumen rencana serta informasi luas lahan maupun peta.

\section{Alat dan Bahan Penelitian}

Tabel 2.1. Alat dan Bahan Dalam Penelitian 


\begin{tabular}{|c|c|c|}
\hline No & $\begin{array}{l}\text { Alat dan } \\
\text { Bahan }\end{array}$ & Fungsi \\
\hline 1 & GPS & Untuk menentukan posisi koordinat pengukuran. \\
\hline 2 & Kamera & Sebagai dokumentasi pengambilan gambar \\
\hline 3 & $\begin{array}{l}\text { Laptop } \\
\text { dengan } \\
\text { aplikasi } \\
\text { ArcGis } \\
\text { Alat - Alat }\end{array}$ & Untuk mengolah data analog ke data digital \\
\hline 4 & $\begin{array}{l}\text { Penunjang } \\
\text { Lainya }\end{array}$ & Untuk membantu kelangsungan pengambilan data. \\
\hline 5 & ArcGis & Sebagai Program untuk mengolah dan menginterprestasi data \\
\hline 6 & $\begin{array}{l}\text { Citra } \\
\text { Satelit }\end{array}$ & Untuk memplot titik koordinat \\
\hline 7 & $\begin{array}{l}\text { Peta } \\
\text { penggunaa } \\
\text { n lahan }\end{array}$ & $\begin{array}{l}\text { Sebagai data mentahserta mengetahui penggunaan lahan dan } \\
\text { infrasktruktur daerah }\end{array}$ \\
\hline 8 & $\begin{array}{l}\text { Alat - Alat } \\
\text { Tulis }\end{array}$ & $\begin{array}{l}\text { Pencatatan/observasi data sekunder sesuai kebutuhan di instansi yang } \\
\text { terkait dengan penelitian }\end{array}$ \\
\hline
\end{tabular}

\section{Prosedur Penelitian}

Prosedur kerja yang akan di lakukan dalam penelitian ini yaitu menggunakan data skunder dan data primer berupa penyusun peta penggunaan lahan. Adapun diagram alir dari gambaran umum prosedur kerja dalam penelitian ini sebagai berikut:

\section{Teknik Pengumpulan dan Analisis Data}

Analisis data dalam penelitian ini untuk mendeskripsikan perubahan guna lahan luasan area penggunaan lahan yang terjadi di tahun 2007 dan 2017.

\section{HASIL DAN PEMBAHASAN}

\section{Hasil Penelitian}

Dalam tahapan pengoperasian penggunaan lahan pada aplikasi ArcGis peneliti lebih dulu mengambil data mentah dari data RBI (Rupa Bumi Indonesia), data mentah Google Earthpro dan peta administrasi Kab.Muna yang kemudian diubah dalam format shapefile (shp). Selanjutnya dalam hal proses pengambilan lahan yang dijadikan sebagai tata guna lahan maka diperlukan data citra googlearth dengan mendigitasi lahan yang diperlukan.

Format shapefile yang telah terkumpul dengan jenis penggunaan lahan selanjutnya kita mendigitasi untuk melihat luasan kawasan lahan yang telah didigitasi. Selanjutnya dalam langkah menyusun sebuah lahan dari produksi data citra diperlukan software ArcGis. Dalam pemrosesan ArcGis data dari citra tersebut dalam format KML selanjutnya diproses pada tools ArcToolbox yang ada pada ArcGis.Hal pertama yang perlu diketahui bahwa dengan laju pertumbuhan penduduk yang ada di Kecamatan Batalaiworu menjadikan perubahan pengggunaan lahan untuk merubah sebuah lahan yang ada semakin meluas. Untuk melihat perubahan suatu luasan dari lahan tersebut, selanjutnya dalam proses pengerjaan pada aplikasi ArcGis, kita dapat memperoleh informasi atribut penggunaan jenis lahan. Atribut informasi 
jenis penggunaan lahan ini peneliti kemudian menampilkan dalam bentuk informasi tabel

seperti pada tabel di bawah ini.

\begin{tabular}{lcccl}
\hline \multicolumn{1}{c}{ Jenis Lahan } & 2007 (ha) & 2017 (ha) & $\begin{array}{c}\text { Perubahan } \\
\text { lahan } \\
\text { (ha) }\end{array}$ & Keterangan \\
\hline Pemukiman & 87 & 155 & 68 & Pertambahan \\
Hutan Sejenis & 469 & 277 & 192 & Pengurangan \\
Kebun & 57 & 144 & 87 & Pertambahan \\
Campuran & 18 & 22 & 4 & Pertambahan \\
Lahan Terbuka & 55 & 58 & 3 & Pertambahan \\
Tambak & 150 & 139 & 11 & Pengurangan \\
Bakau & 86 & 97 & 11 & Pertambahan \\
Lahan Kosong & & & & \\
\hline
\end{tabular}

\section{Sumber :Data diolah 2018}

Perolehan data informasi ini diperoleh saat pengerjaan peta dengan mendigitasi area/wilayah dan akan memperlihatkan kita bertambah atau berkurangnya perluasan perubahan jenis penggunaan lahan di Kecamatan Batalaiworu. Selanjutnya dengan bantuan aplikasi ini kita juga dapat membuat dan melihat pola sebaran lahan pada tahun 2007 dan 2017 di Kecamatan Batalaiworu. Untuk melihat peta pola sebaran penggunaan jenis lahan dapat dilihat pada gambar dibawah ini

\section{Gambar 3.1 Peta Penggunaan Lahan Tahun 2007}

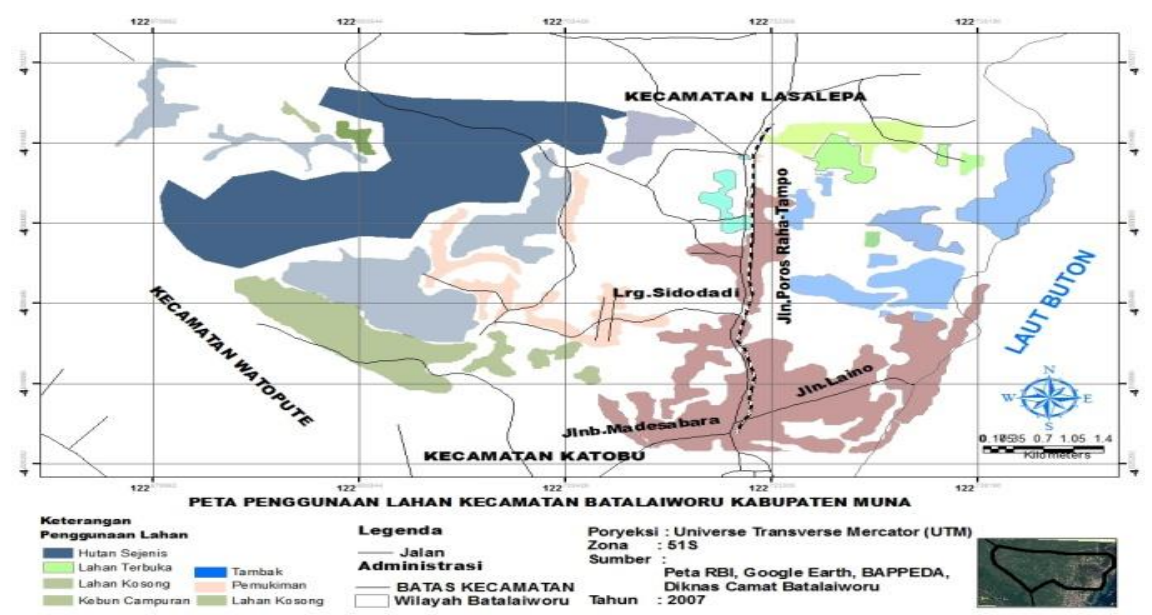

Sumber :Data diolah (2018)

Gambar 3.2 Peta Penggunaan Lahan Tahun 2017 


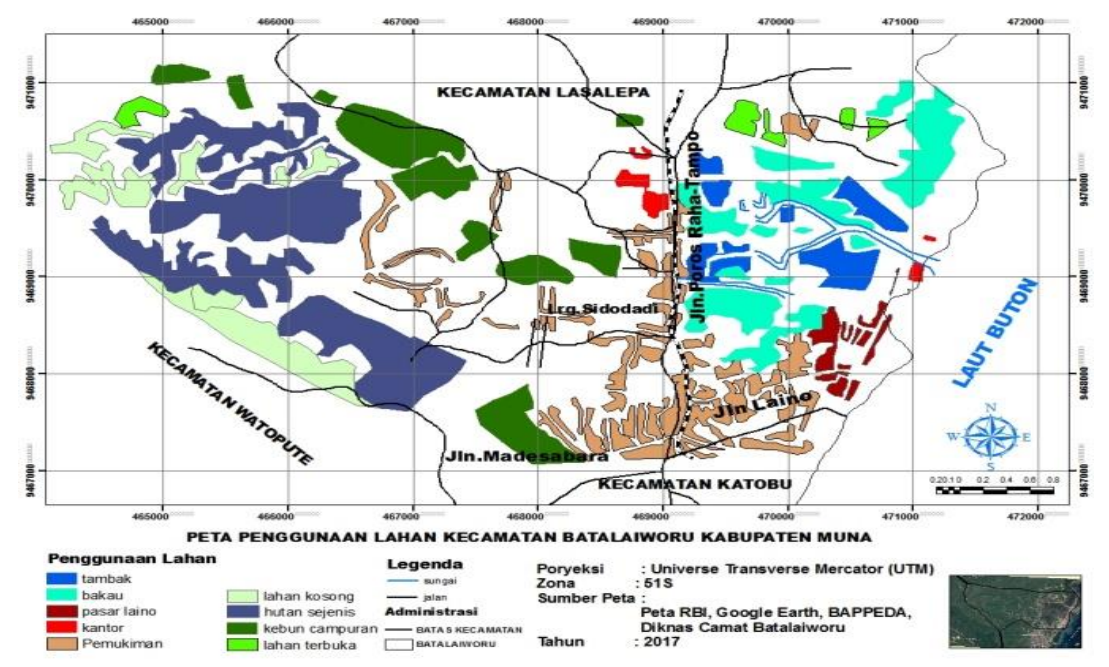

Sumber :Data diolah (2018)

Selanjutnya dalam proses pengerjaan aplikasi ArcGis di atas, kita dapat memperoleh informasi atribut penggunaan jenis lahan. Atribut informasi jenis penggunaan lahan ini peneliti kemudian menampilkan dalam bentuk informasi tabel seperti pada tabel.

\section{Deskriptif Penggunaan Lahan 2007 Dan 2017 \\ Pemukiman}

Berdsarkan tabel di atas, peneliti akan mulai membahas penggunaan lahan untuk pemukiman dalam kurun waktu 11 tahun di Kecamatan Batalaiworu yaitu pada tahun 2007 dan 2017. Untuk penggunaan lahan pemukiman tahun 2007 dan 2017 perubahan lahan pemukiman mengalami peningkatan luasan yaitu dari 87 ha menjadi 155 ha sehingga mengalami pertambahan luasan kawasan. Pertambahan luasan lahan pemukiman ini difaktorkan kepadatan penduduk di Kecamatan Batalaiworu. Seperti pada artikel "Batalaiworu dalam Angka 2017" juga menyebutkan bahwa perubahan lahan pemukiman di sebabkan oleh meningkatnya pertambahan jumlah penduduk.
Pada gambar peta penggunaan lahan untuk pemukiman pola sebaran keepadatan penduduk berada pada Kelurahan Laiworu berlokasi di Jln.Madesabara Ujung (Kontu) disebabkan oleh perubahan fungsi lahan dari hutan lindung menjadi pemukiman pengalih fungsi lahan yang kurang memperhatikan kualitas biofisik lingkungan. Alih fungsi lahan terjadidi Kecamatan Batalaiworu dalam pemenuhan aktivitas sosial ekonomi yang menyertai pertumbuhan penduduk kota.Lahan yang memiliki potensi dan strategis, akan berpeluang mengalami perubahan alih fungsi lahan untuk perkembangan fisik kota. Tren yang paling nampak yakni jika berkembang prasarana jalan maka akan bermunculan kawasan perumahan dan permukiman di sekitar kawasan tersebut karena daya tarik pencapaian lokasi yang mudah dan cepat seperti halnya di kawasan Jl.Madesabara(Kontu).dan terendah di Desa Wawesa. Dengan melihat pola penyebaran pada peta di atas, kepadatan penduduk bearada di lntas jalan, sekitar kantor/gedung pelayanan dan pusat perbeanjaan.

\section{Lahan Terbuka}

Penggunaan lahan untuk lahan terbuka yang ada di Kecamatan Bataliworu seperti pada data tabel, tahun 2007 dan 2017 mengalami pertambahan luasan yang tidak 
terlalu signifikan, luasan lahan tahun 2007 yaitu 18 ha dan 2017 adalah 20 ha. Di indikasikan bahwa lahan terbuka yang ada ini, dikarenakan terbentuknya disebabkan oleh manusia. Lahan yang telah dibuka kemudian ditinggalkan sampai beberapa tahun sehingga meninggalkan lahan yang sedikit kosong.

Selanjutunya berdasarkan gambar peta pola penyebaran jenis penggunaan lahan ini, lahan terbuka mengalami penambahan di kawasan perumahan BTN Jln.Madesabara, Jln.Gatot Subroto lapangan tembak Kodim dan di depan Kantor Bupati Muna.

\section{Lahan Campuran}

Penggunaan lahan untuk kebun campuran yang ada di Kecamatan Batalaiworu seperti pada tabel, tahun 2007 dan 2017 terjadi pertambahan luasan yang signifikan, data tahun 2007 yaitu 57 ha dan 2017 adalah 144 ha. Perlu diketahui bahbwa kebun campuran berupa lahan yang ditanami lebih dari satu jenis atau tidak seragam dan biasanya diusahakan secara tradisional oleh penduduk.

Selanjutnya data diatas dikelola deangan aplikasi ArcGis diperoleh bahwa peta pola penyebaran peta penggunaan lahan kebun campuran tersebar seperti pada gambar di atas. Terlihat bahwa penambahan luasan kawasan kebun campuran terdapat di Jln.Madesabara Ujung yang sebelumnya merupakan Hutan Lindung berubah menjadil kebun warga setempat dan kebanyakan terjadi juga di Kleurahan Wawesa. Perubahan luasan kebun campuran ini diakibatkan oleh polah kehidupan penduduk masih bercocok tanam dan sering berpindah-pindah.

\section{Hutan Sejenis}

Penggunaan lahan untuk hutan sejenis yang ada di Kecamatan Batalaiworu seperti pada tabel, tahun 2007 dan 2017 terjadi perngurangan luasan yang cukup signifikan yaitu data tahun 2007 yaitu 469 ha dan 2017 adalah 277 ha. Untuk hutan sejenis yang terdapat pada Kecamatan Batalaiworu sampai dengan Kontu dan Watu-Watu kebanyakan berupa hutan jati.

Selanjutnya data diatas dikelola dengan aplikasi ArcGis diperoleh bahwa peta pola penyebaran peta penggunaan lahan hutan sejenis tahun 2007 tersebar seperti pada gambar di atas. Namun dalam kurun waktu 11 tahun yaitu tahun 2017 mengalami pengurangan lupasan kawasan. Terlihat bahwa pengurangan luasan kawasan hutan sejenis terdapat di Jln. Kontu yang sebelumnya merupakan Hutan Jati yang dilindungi oleh pemerintah kemudian berubah lahan kosong, kebun dan rumahrumah penduduk. Perubahan luasan hutan sejenis ini diakibatkan oleh polah kehidupan penduduk masih tidak memperdulikan lingkungan, sehingga penduduk dengan seenaknya saja merubah hutan jati menjadi kawasan perkebunan, dan lemahnya hukum, sehingga banyaknya hutan yang telah berubah fungsi dari nfungsi pokoknya menjadi lahan kebun, serta ikut berpindahpindahnya baik untuk bercocok tanam ataupun sebagai pemukiman.

\section{Lahan Bakau}

Penggunaan lahan untuk lahan bakau yang ada di Kecamatan Batalaiworu seperti pada tabel, tahun 2007 dan 2017 terjadi perngurangan luasan data tahun 2007 yaitu 150 ha dan 2017 adalah 139 ha. Untuk lahan bakau berlokasi di pesisir pantai.Sama halnya sebelumnya selanjutnya dikelola dengan aplikasi ArcGis diperoleh bahwa peta pola penyebaran peta penggunaan laahan bakau tahun 2007 tersebar seperti pada gambar di atas. Terlihat bahwa pada pengurangan luasapn kawasan bakau tahun 2017 ter dapat di wilayah pesisir pantai sepanjang teluk. Pengurangan kawasan bakau ini umumnya biasanya terdapat pada kawasan penimbunan baik dijadikan penambahan rute jalan, penambahan gedung, pengambilan hasil 
bakau tidak terkendali atau dengan kata lain kawasan bakau belum dibudidayakan. Peningkatan kegiatan yang terjadi pada kawasan penimbunan yang akan meningkatkan pemnafaatan lahan, sehingga menimbulkan implikasi terhadap kualitas perairan dan ekosistem pesisir (mangrove, lamun dan terumbu karang). Kecenderungan terjadinya peningkatan pemanfaatan lahan untuk pengembangan kegiatan permukiman dan pengembangan sarana dan prasarana, mengakibatkan penurunan kualitas perairan.

Sehingga keberadaan bakau tidak terlalu di perhatikan. Terbukti berdasarkan hasil daripengelolaan yang diperlihatkan oleh gambar peta penyebaran penggunaan lahan bakau tahun 2007 memperlihatkan pengurangan penyebaran di tahun 2017.

\section{Tambak}

Penggunaan lanhan untuk tambak yang ada di Kecamatan Batalaiworu seperti pada tabel, tahun 2007 dan 2017 terjadi penambahan, data tahun 2007 yaitu 55 ha dan 2017 adalah 58 ha. Untuk budidaya lahan tambak berlokasi di bagian aliran sungai yang ke laut atau hulu.

Pada pengelolaan dengan aplikasi ArcGis diperoleh bahwa peta pola penyebaran paeta penggunaan lahan tambak tahun 2007 tersebar seperti pada gambar 4.1 di atas. Terlihat bahwa pada penambahan luasan kawasan tambak tahun 2017 terdapat di kawasan aliran sungai. Penambahan kawasan tambak ini menurut hasil observasi dengan pemilik tambak sendiri karenakan hanya hobi saja dan pada umumnya orang yang memiliki tambak adalah tergolong ekonomi tinggi. Budidaya tambak memiliki komponen keruangan serta perbedaan karakteristik biofisik dan sosial ekonomi dari setiap lokasi. Banyak tambak intensif belum memanfaatkan kelebihan sistem informasi geografis dalam melakukan pemilihan lokasi dan pengelolaan budidaya, dimana hal tersebut penting dilakukan untuk menghindari kegagalan usaha.

\section{Lahan Kosong}

Penggunaan lanhan untuk lahan kosong yang ada di Kecamatan Batalaiworu seperti pada tabel, tahun 2007 dan 2017 terjadi penambahan, data tahun 2007 yaitu 86 ha dan 2017 adalah 97 ha. Untuk lahan kosong berlokasi di kawasan perubahan hutan sejenis menjadi kebun campuran dan kebanyakan terbentuk karena proses berpindah-pindahnya lokasi bertani dan meninggalkan tanpa perawatan sehingga menjadi lahan kosong.

Selanjutnya dikelola dengan aplikasi ArcGis diperoleh bahwa peta pola penyebaran paeta penggunaan lahan lahan kosong tahun 2007 tersebar seperti pada gambar 4.1 di atas. Terlihat bahwa pada penambahan luasan kawasan tambak tahun 2017 terdapat di kawasan perubahan fungsi lahan. Penambahan kawasan lahan kosong ini menurut hasil observasi sendiri dikarenakan penduduk merubaha fungsi lahan dan menjadikan lahan tersebut kosong. Perpindahan ini kebanyakan disebabkan tanah yang mereka garap awal sudah tidak produktif lagi.

Lahan kosong pada wilayah penelitian memiliki dampak ekonomi yaitu menurunnya penerimaan PAD dari sektor pajak bagi pemerintah. Di samping itu juga mengakibatkan dampak sosial, yaitu hilangnya kesempatan peluang kerja dan dampak terhadap produksi panganDengan kata lain lahan yang tak termanfaatkan pada wilayah penelitian memiliki dampak negatif terhadap perekonomian pemerintah dan masyarakat.

\section{KESIMPULAN}

Dari hasil pemetaan yang telah dilakukan dengan Sistem Informasi Geografis peneliti berkesimpulan bahwa:

1. Perubahan luasan penggunaan lahan tahun 2007 dan 2017 mengalami perubahan yaitu untuk pemukiman mengalami pertambahan luasan lahan dari 87 ha menjadi 155 ha, untuk hutan 
sejenis mengalami pengurangan luasan lahan dari 469 ha menjadi 277 ha, untukj lahan kebun campuran mengalami pertambahan luasan dari 57 ha menjadi 144 ha, untuk lahan terbuka mengalami pertambahan luasan dari 18 ha menjadi 22 ha, untuk tambak mengalami pertambahan luasan dari 55 menjadi 58 ha, uantuk bakau mengalami pengurangan luasan lahan dari 150 ha menjadi 139 ha, untuk lahan kosong mengalami pertambahan luasan dari 86 ha menjadi 97 ha.

2. Pola sebaran perubahan penggunaan lahan yang terdapat di Kecamatan Batalaiworu kebanyakan disebabkan oleh pertambahan jumlah penduduk, pertambahan jumlah penduduk dapat mempengaruhi perubahan luasan lahan.

\section{Saran}

Adapun saran yang dapat diberikan dari peneliti adalah hasil yang diperoleh dalam studi ini dapat dijadikan sebagai acuan dalam analisis selanjutnya, terutama terkait dengan survei dan pemetaan penentuan pola tata ruang penggunaan lahan di kawasan Kecamatan Batalaiworu.

\section{DAFTAR PUSTAKA}

Aronoff, Stan, 1989. Geographic Information Systems: a Management Perspective. Ontario: WDL Publications.

Bintarto. 1977. Pola Kota dan Permasalahan Komprehensif: Pengantar danPenjelasan. Gadjah Mada University Press: Yogyakarta.

Prahasta, Eddy.2004, Sistem Informasi Geografis Tools dan Plug-In, Informatika, Bandung.

2005, Konsep-Konsep Dasar Sistem
Suharto Widjojo dan Sambiyo, 1991, Peranan Sistem Informasi Geografi (GIS) dalam Pengelolaan Sumberdaya Hutan di Indonesia, Majalah Forum

Su Ritihardoyo. 2002. Penggunaan dan Tata Guna Lahan. Fakultas Geografi,Universitas Gadjah Mada, Yogyakarta. 
